\title{
A Manifesto for a Progressive Land-Grant Mission in an Authoritarian Populist Era
}

Jenny E. Goldstein, Kasia Paprocki, Tracey Osborne

\begin{abstract}
In this essay, we offer a manifesto for a progressive 21 st century land-grant mission in an era of rising authoritarian populism in the United States. We explore the historical context of this mode of political engagement, argue that scholars based at land-grant universities are uniquely positioned to address this political moment, and offer examples of land-grant scholars who have embraced this political obligation directly. In the midst of the U.S. Civil War, the federal government provided grants of land to one college in every state to establish universities especially with extension-oriented missions committed to agricultural research and training; today, there are 76 land-grant universities. Just as the constitution of these universities at a significant moment in the country's history served a political purpose, the current political climate also demands a robust political response from contemporary land-grant scholars. Given the mandate for land-grant universities to serve their communities, how can a critical land-grant mission respond to the current political moment of emergent authoritarian populism in the U.S. and internationally? What responsibilities are entailed in the land-grant mission? We consider some strategies land-grant scholars are employing to engage with communities grappling most directly with economic stagnation, climate change, and agrarian dispossession. We also suggest that, amid the dramatically shifting political climate in the U.S., all scholars regardless of landgrant affiliation should be concerned with land-grant institutions' capacity to engage with the country's most disenfranchised populations as a means to pushing back against authoritarian populism.
\end{abstract}


Keywords: land-grant institutions, higher education, authoritarian populism, public geographies, United States

\section{Introduction $^{i}$}

America's land-grant universities were founded with the goal of serving the economic and political needs of the communities in the states in which they are based, and ensuring the relevance of scholarly research to addressing practical social concerns (Bonnen 1998). Throughout their history, these institutions have been subject to repeated calls to renew this mandate and how they pursue this engagement in light of new political, economic, and demographic demands (Cochrane 1979; Campbell 1995; National Research Council 1996; Kellog Commission 1999; Peters 2006). Concerns about the relevance of land-grant scholarship are embedded in broader debates about expertise and democracy, the purpose of academia, and its obligations to society (McDowell 2003; Peters et al. 2008). In this article, we situate these land-grant institutions historically to explain why the current political moment demands a renewed commitment to this mandate. We demonstrate how the political challenges presented by authoritarian populism are inextricably linked with the mandate of land-grant institutions to engage more deeply and meaningfully with their communities.

Amid Civil War and in the wake of the Industrial Revolution - a moment of social, political, and economic upheaval in the United States-Abraham Lincoln signed the Morrill Act of 1862 into law, establishing the country's first land-grant universities. With one land-grant in each state, these institutions were created to support communities in the states in which they were based through research, teaching, and extension work. At their founding, land-grant universities were 
one of the clearest elaborations of democratic ideals in U.S. higher education: an egalitarian opportunity for all Americans, not only elites, to find pathways for university study, particularly through engagement with the agricultural sciences. Yet, from the beginning there was ambiguity and conflict over what was entailed in this vision and how it could be achieved. Gelber writes that at their founding in the late nineteenth century, rival visions he characterizes as elitist and populist struggled over the character and content of land-grant research and education (Gelber 2013). The land-grant mission has thus always been tied to broader political currents, through continued financial support from state and federal governments, and served an important role in social and economic development locally, nationally, and even globally. Simultaneously, the land-grant mission, with its emphasis on community participation, also provides opportunities for more progressive research, education, and public engagement. In this essay, we argue that scholars based at land-grant universities have an opportunity to directly address rising strains of authoritarian populism in contemporary U.S. politics through their positions in these unique institutions. This means both confronting the systems of power that have shaped the current political moment and grappling with the role of knowledge generated by land-grant university scholars in that process. Even as we do so, we acknowledge that the challenges that authoritarian populism poses to our universities and communities are deeply structural, and cannot be addressed by individual scholars alone. Nevertheless, we find that the land-grant mandate offers important openings for constructing spaces of resistance to authoritarian populism. We identify opportunities to forge new alliances, collectivities, and platforms for developing and pursuing grounded alternatives.

While the fundamental land-grant mission has remained largely static since its inception, their political and economic context has changed dramatically, placing new demands on how land- 
grant scholars carry out their work. Land-grant institutions were established with a mandate to foster 19th and 20th century fossil fuel-dependent development in the industrial and agricultural sectors, which has had serious social and environmental implications on multiple scales, including climate change. Relatedly, the communities which land-grant institutions were mandated to serve have also shifted, from being once exclusively white and agrarian to now encompassing communities of color, indigenous groups, and the rural and urban poor. Such marginalized communities have been made further vulnerable by the fallout from the imposition of international trade policy, agricultural industrialization, new energy regimes, and associated demographic and labor transformations. Such systemic economic transformation has often preceded changes in the political climate within such communities. Nationally, the authoritarian populist assault on science via the promotion of "alternative facts" has found a sympathetic audience among voters whose trust in scientific authority has dwindled, along with their trust in political elites (Brown 2014, Canovan 1999). President Trump's promotion of a "post-truth" altreality is thus part of a longer trajectory of weakening confidence in science along with rising distrust of institutions more generally (Gauchat 2012, Putsche et al. 2017). Understanding this hegemonic project will require not only interrogating the Trump administration and dominant political and economic elites who have promoted this assault, but also seeking to understand the social conditions under which consent for this "post-truth" era has been authorized. We must also be reflexive in our examination of the ways in which this distrust has risen out of our own insistence on the power of experts over public participation in policy making (Forsyth 2011), on objectivity over multiple and situated knowledges (Steinmetz 2005), and on technocracy over democracy (Guidotti 2017). 
Following Scoones and colleagues (Scoones et al. 2018), we understand the current political conjuncture in line with the dynamics of authoritarian populism described by Stuart Hall at the height of the Thatcherite movement in the 1980s (Hall 1980, 1985). For Hall, authoritarian populism is a form of hegemonic class politics, and he therefore focuses his attention on its political-ideological dimensions (cf. Jessop et al. 1984, Brubaker 2017). Hall in particular calls out the "educative role" of the state in constructing this populist consensus (Hall 1985, 116; 1980, 180). We find Hall's formulation useful in that it directs us to the specifically political dimensions of knowledge production and the assembly of "common sense" (Gramsci 1971). Hall's analysis of the authoritarian populism of the Thatcherite movement resonates deeply with Trump-era authoritarian populism in the sense of crisis to which it responds and which it generates, in the racism and xenophobia that authorize it (Scoones et al. 2018). As Scoones and colleagues explain, authoritarian populism "typically depicts politics as a struggle between 'the people' and some combination of malevolent, racialized and/or unfairly advantaged 'Others', at home or abroad or both" (ibid. 2). In considering the role of land grants in this unique historical moment, we derive inspiration from these theorists who trace the dialogic relationship between "the knowledge of the intellectuals and popular opinion" (Crehan 2016, xii), and who thus address themselves to the responsibilities of intellectuals to political engagement. Although this populism has been manifested in a variety of national contexts across Europe and the United States (Brubaker 2017, Edwards et al. 2017, Ulrich-Schad et al. 2018), we focus here on the U.S. in order to highlight the unique obligations of American land-grant universities.

In this context, what is the role of land-grant institutions and the land-grant mission in creating and disseminating environmental knowledge vis-à-vis rising tides of authoritarian populism in the U.S.? How can land-grant scholars ensure their work serves the communities in which they 
are based, and their most marginalized members in particular? What is the role of land-grant scholars within increasingly neoliberal universities that, given reduced public support, seek funding from corporations, which have themselves contributed to the insecurity of poor and vulnerable communities in both rural and urban environments? In this essay, we argue that we need to rethink the role of land-grant institutions vis-à-vis the current political conjuncture. To that end, it is necessary to reckon with the history of the land-grant mission, the institutions tasked with carrying it out, and their role in shaping the present political climate in the U.S.. We then propose several ways that scholars based at land-grant universities might confront the rising tide of authoritarian populism and its assault on scientific expertise in civic discourse.

\section{Land-Grant Universities in U.S. Agrarian History}

Although the land-grant system was not developed exclusively to serve the needs of rural communities (Bonnen 1998, 28), this has been an important objective for many of the universities. ${ }^{\text {iii }}$ Initial interest in a university system that would educate America's rural population began in the 1840 s, a time at which "the so-called farmer's vote in America was becoming increasingly self-consciously political” (Brubacher 1997, 62). This moment saw an upsurge of agrarian populism from both the left and right, ${ }^{\mathrm{iv}}$ and demands from some farm organizations that university education be made available and relevant to the agrarian class, rather than only elites pursuing liberal arts. In July 1862, as escalating Civil War battles were raging in Virginia, President Abraham Lincoln signed into law the Morrill Land-Grant College Act. The Act granted each state federal land in proportion to their state's congressional representation. The capital states earned from this land through investment and/or sale was to support the endowment and maintenance of at least one university in each state that upheld the 
objective to teach, without excluding scientific and classical research, agriculture, mechanic arts, mining, and military tactics. Such pursuits were established to "promote the liberal and practical education of the industrial classes in the several pursuits and professions in life." (July 2, 1862, ch. $130, \S 4, \underline{12}$ Stat. 504). Today there are 76 such institutions across the United States and its territories.

The role of these universities in serving agrarian communities was never entirely coherent, however. The focus on agricultural development in rural areas has been largely the purview of the Cooperative Extension Service, formalized in 1914 through the Smith-Lever Act to ensure the access of American farmers to the insights of the agricultural sciences (McDowell 2003). The extension work of these programs is one way that land-grant mission has been pursued; however, it is not the only platform through which the land-grant universities have been mandated to serve broader publics. University accessibility, for instance, has been an issue since the land-grants were founded, since the majority of students admitted in the first decades were white and male. U.S. Congress sought to address this inequality by signing into law the second Morrill Act of 1890, which designated several historically black colleges as land-grants tasked with the same mandate as the original institutions. ${ }^{v}$ A century later, U.S. Congress provided funding under the 1994 Improving America's Schools Act for 36 land-grant colleges affiliated with Native American tribes (Halvorson 2016, Mack and Stolarick 2014). While land-grant-funded historically black colleges and those located in indigenous communities have played an important role in serving rural populations and the wider communities within which they operate (Williams and Williamson 1988), and thus in meeting the demands we lay out in this piece, they are not without critiques. As Harper et al. (2009) discuss, designating black colleges as landgrant schools further entrenched segregation, since other land-grant universities could justify 
denying admission to black students. Most of the historically black land-grant colleges also fell consistently behind their peer institutions in terms of public funding rates and quality of education (Harper et al. 2009). This speaks to continued tensions since their founding over which publics land-grant universities should be serving and how they might continue to do so today, as demographics in many states have shifted towards urban, non-white populations.

Although land-grant university extension work arose in response to demands of farm advocacy groups, suggesting that their role was to serve farming communities, land-grant universities were enrolled in deleterious agrarian transitions in the rural United States. ${ }^{\mathrm{vi}}$ As agricultural economist Willard Cochrane wrote, "the colleges of agriculture never became the training institutions for future farmers that their founders had envisaged... [yet] they have served for at least seventy-five years as a wonderfully efficient channel for helping young men and women transfer out of agriculture and into productive nonfarm pursuits" (Cochrane 1979, 107). ${ }^{\mathrm{vii}}$ In this way, Cochrane places the land-grant colleges at the center of his narrative of rural demographic transition, alongside other systemic policy interventions that transformed the agrarian political economy of the United States (Friedmann and McMichael 1989). Yet, in contrast with Cochrane's cheerful assessment of rural-urban transition, the rural economic decline that has led to this demographic shift has not always met with such celebration among rural communities. Throughout the midtwentieth century, agricultural mechanization and a variety of forms of technological advancement (particularly in agricultural chemicals and biotechnology), largely based on fossil fuels, led to extreme pressures on the small farm, displacing both smallholders and agricultural laborers, leading to widespread dispossession of agrarian land (Buttel and Busch 1988, Williams and Williamson 1988). Researchers at land-grant institutions have been implicated in this transition directly, with several scholars and commentators noting the close relationships 
between land-grant institutions and agribusiness companies (Buttel and Busch 1988, Hightower 1972, Williams and Williamson 1988). A 1990 study by two Cornell University social scientists found that land-grant researchers were even more likely to have closer relationships with the biotechnology industry than their counterparts at other research universities (Curry and Kenney 1990).

\section{Land-Grant Universities Under Neoliberalism}

These close linkages continue to shape research conducted at land-grant institutions in powerful ways. ${ }^{\text {viii }}$ As U.S. agriculture has shifted from small family-centered farms to agribusinessdominated production dependent on migrant labor and global commodity chains, so too have the beneficiaries of land-grant extension work. Land-grant universities now depend on external funding from some of the world's largest corporations for agricultural extension, for instance Monsanto-funded research on genetically modified organisms (GMOs), with the resulting intellectual knowledge becoming property of the private sector rather than a public good (Glenna 2017). Through this imbrication with private investment, land-grant universities have come to play a critical role in the work of "rendering land investible" (Goldstein and Yates 2017, Kenney-Lazar and Kay 2017). The effects of such privatization of agricultural knowledge, increased capital accumulation by agribusiness, and rural land consolidation have clearly expressed themselves in electoral politics, although not always in uniform or obvious ways (Lewis-Beck 1977). A growing rural-urban divide manifests itself in what political scientist Katherine Cramer calls "the politics of resentment" (Cramer 2016). The discontent of those impacted by these processes of agrarian dispossession can exist within rural communities but also in migrant-receiving communities, in particular small towns classified as "non-metropolitan 
areas", and the industrial rust-belt (Lichter and Ziliak 2017). Rural economic distress has played a major role in the rise of authoritarian populism today; this pattern is even clearer if we attend to these geographies produced by political economic transformation. Although media reports often erroneously flatten an analysis of voting trends in the 2016 election to suggest that rural, white working-class voters are responsible for Trump's victory (Butler 2017, Gusterson 2017), some demographers have offered a more nuanced picture of the political economic transformations that it represents. Monnat and Brown (2017) demonstrate that the electoral shift that gave rise to Trump's 2016 victory grew out of "landscapes of despair" produced by a dramatic decline in jobs in manufacturing and natural resource industries since the 1970s. These communities within the rural-urban continuum should be understood not only as post-industrial but also when analyzed historically as post-agrarian. The role of land-grant institutions described above in transforming the agrarian political economy of these communities as well as their mandate to serve their needs must be reflected on by land-grant scholars today.

In addition to the role of land-grant institutions in the transformation of agrarian political economies, this history also highlights the contentious politics of knowledge production that fuels the rise of 21 st century authoritarian populism as well. These transformations impact public institutions in particular, but they are not limited to land-grant universities. The political economy of knowledge production within the land-grant university has developed within a broader context of privatization and neoliberalization of American science and higher education over the past three decades (Newfield 2016, Busch 2017, Mirowski 2011, Lave 2012). Yet, as Prudence Carter, Dean of the Graduate School of Education at the University of California, Berkeley (a land-grant university) points out, even as privatization has threatened the values of education as a public good in the United States, many public universities were already largely 
inaccessible to many of the most marginalized constituencies they purport to serve (Carter 2018). Thus, threats to the public mission in research and education of both land-grant universities and public institutions more broadly are both acute and secular. We must understand the threats and challenges to the 21 st century land-grant universities within this wider historical context. Glenna suggests that deliberation on these transformations and the purpose of research within public universities is an important first step in resisting the privatization of university science (2017).

\section{Elements and Examples of a Progressive Land-Grant Mission for the $21^{\text {st }}$ Century}

Against this history, we offer a type of manifesto for the $21^{\text {st }}$ Century land-grant. We argue that the work of land-grant scholars in this moment of authoritarian populism must integrate research, teaching and service and focus on three main points: 1) Provide inclusive education that is accessible and affordable, 2) serve the needs of the regions in which they are situated, including both rural and urban residents, in ways that help them build more self-sustaining, thriving communities, 3) orient around sustainability and social justice. These are some of the characteristics of the New American University (Crow and Dabars 2015). Some elements of this vision are also linked with early and long-standing populist visions for the land-grant mission, ${ }^{\text {ix }}$ particularly those of accessibility (including late 19th century calls for free or inexpensive higher education), and those concerned with addressing class inequality (Gerber 2013). Thus, they offer possibilities for reconciling the challenges of authoritarian populism with a more progressive vision of land-grant education and scholarship.

Accessibility 
First and foremost, we must ensure that higher education is accessible to all students, particularly the rural and urban poor. Public education is under attack at all levels in the United States, and rising costs of higher education jeopardize our mission to equal access to education for all. Furthermore, the proposal to end the Deferred Action for Childhood Arrivals (DACA) program threatens undocumented young people, who are among our most vulnerable students. Some colleges and universities have implemented programs to better ensure students are not denied higher education due to financial constraints. These include New York's Excelsior Scholarship that provides free tuition for students and families of the state who earn less than $\$ 125,000$, and Arizona State University's President Barack Obama Scholars Program that provides free tuition and additional support for students of families that makes $\$ 42,400$ or less so that they graduate debt free. These types of programs improve education accessibility for income poor students, and could be further developed within land-grant institutions.

Carter suggests that administrators at public institutions pursue this expanded accessibility by working to adapt the metrics by which the work of public institutions are measured. Ranking institutions based on the test scores of their successful applicant pool undermines the mission of democratizing accessibility. "Frankly," Carter writes, "the strong positive correlation among test scores, socioeconomic status, and school quality raises legitimate questions about the objectivity and fairness of required admissions tests" (Carter 2018, 495). She explains that alternative metrics would help these institutions to better serve their unique mandate, which suggests different opportunities and responsibilities in education from those of private institutions. She suggests a first step could be withdrawing from the U.S. New and World Report national rankings, which force public institutions to compete with private institutions on unequal terms (Carter 2018). 


\section{Engaging rural and urban publics}

Land-grant scholars today can also work to integrate community engagement into their work at all levels, including the research methods, subjects, and questions they choose to pursue. Landgrant institutions were founded to support regional development and have largely emphasized agricultural extension. Today, however, the global population is increasingly urban with different sets of needs than those existing at the establishment of land-grant colleges and universities (McDowell 2003). In recent decades, colleges and universities have embraced engaged scholarship, expanding opportunities for faculty and students to pursue community-focused research in partnership with public entities (Boyer 1990, Barker 2004). Beyond the extension model often seen unidirectional with regards to the flow of information and resources from the university, engaged scholarship values the co-production of knowledge and seeks to bridge the divide between academia, government, the private sector, and community groups in order to improve environmental conditions and human well-being. Engaged scholarship actualizes networks with the potential to harness the untapped resources at universities to affect positive social-environmental change. While universities have emphasized relationships with government and industry, we argue that the new mission of land-grant universities must emphasize public scholarship that engages communities in science that matters to members of the communities themselves.

Researchers at Michigan State University (MSU) fully embodied this community-oriented mission when, in 2015 they identified, exposed, and responded to the drinking water crisis in Flint, Michigan. Problems with elevated lead levels in children's blood in Flint were first 
identified by Dr. Mona Hanna-Attisha, a professor in the MSU College of Human Medicine who also practices as a pediatrician in Flint. Despite state officials accusing Dr. Hanna-Attisha of creating "hysteria" (Goodnough, Davey and Smith 2016), along with two Flint public health officials and an MSU urban geographer, her published findings (Hanna-Attisha et al. 2016) ultimately forced state and federal officials to accept and address the problem, leading to the declaration of a federal state of emergency (Carravallah et al. 2017). The water crisis in Flint was itself fundamentally bound up in contemporary modes of racialized urban dispossession (Ranganathan 2016). The ideological foundations of these modes of dispossession disregard their structural underpinnings. Thus, a deeper response to the crisis currently facing Flint involves not only immediate action to repair the infrastructure responsible for this mass poisoning, but also addressing the ideological hegemony sanctioning its structural drivers. For example, linking the water crisis with historically racist housing and urban development practices (Sadler and Highsmith 2016), researchers have responded with a variety of extension projects in food systems, political advocacy, and public health (Michigan State University 2017).

\section{Sustainable development and social justice}

Pursuing this progressive vision of the 21 st century land-grant mandate will also require centering sustainable development and social justice at the heart of this engaged research and pedagogy. Human impact on the planet and unprecedented social and environmental changes can be traced to unsustainable industrial and agricultural development, largely driven by fossil fuels. Land-grant institutions have been central to the roll out of the industrialization process now pegged as the start of the Anthropocene: the era in which humans have significantly impacted Earth systems function, most powerfully evidenced by the global climate change crisis. 
Therefore, land-grant institutions responsive to current political and ecological dynamics must have sustainability as a central pillar of research and teaching. Environmental issues such as climate change are social and political problems; as such, they cannot be addressed in disciplinary silos, but require an interdisciplinary approach. Furthermore, these problems can not be solved by technological fixes alone, they require approaches that address the root political economic drivers of environmental change and lay the groundwork for a just transition to a more sustainable future (Paprocki 2018).

Many geographers and land-grant scholars have pursued this mission through communityoriented pedagogies (Trudeau et al. 2018). Ryan Galt et al. (2012) describe one model for teaching agriculture and food systems at a land-grant university (University of California, Davis) that brings a "critically reflexive research perspective to teaching" in ways that enhance student learning outcomes and raises awareness of the social justice aspects of food systems. Through development of a food systems course based around a student-centered, non-hierarchical structure, the instructors advocate for transformational learning experience in the classroom as a means to enabling students to become "active knowledge producers, engaged citizens, and democratic members of our global community--to ultimately change the food system and the world" (140). Although this model could be brought to any university, it has particular salience for engaging students at land-grant institutions as a means for them to take responsibility to enact change in local communities as well as in communities at a distance. Furthermore, while upholding the original land-grant mission of bringing university knowledge to agrarian communities, the emphasis on non-hierarchical, critically reflexive learning is a more progressive way to work with non-academic communities to advance social and environmental justice. 
An example of engaged scholarship with a strong research and service focus is the Climate Alliance Mapping Project, a collaborative effort between academics at the land-grant institution the University of Arizona, environmental organizations and Indigenous groups (Osborne 2017). Following the articulated values of non-academic partners, CAMP identifies, maps, and shares information about the fundamental drivers of climate change, priority areas for keeping fossil fuels underground, and the location of pipelines and pipeline spills, especially those that cross important waterways. CAMP makes features such as pipelines more transparent and visible on the landscape in order to support activist campaigns, build broad-based alliances, increase public awareness and influence climate policy to better support climate justice efforts. Inspired by decolonizing methodologies, CAMP uses a more horizontal approach to research that incorporates the interests and questions of activist partners in Arizona and abroad. In this way the research is more meaningful to not only the researchers' non-academic partners but to the broader publics they serve.

\section{Conclusion}

To some geographers at land-grant institutions, the entreaties to maintain and broaden public education accessibility, serve the needs of urban and rural publics through a co-production of knowledge, and emphasize sustainable development and social justice will be preaching to the choir. But for others who have not grappled with the implications and responsibilities shared amongst scholars at such institutions, and even for those who enact the land-grant mission in practice but have not considered the mission's particular relevance to today's political climate, we call for a rethinking of the land-grant's mission within its broad historical context. 
The problem of authoritarian populism, and the wider context of neoliberalization confronting our universities, is deeply structural. We have no intention of suggesting otherwise. Land-grant faculty are not individually equipped to resolve these structural concerns. Glenna rightly points to the folly of piling "expectations on university scientists to heroically resist science commercialization in the face of political, economic, and university pressures" $(2017,1029)$. Neither is this our intention. And yet, we find it politically necessary to pursue strategies for confronting these challenges, and we find spaces of hope and the possibility of resistance in the promise of the land-grant mandate.

Resistance will need to be exercised on several fronts. Individual scholars will find that they are institutionally and personally equipped to pursue some of these strategies better than others. ${ }^{\mathrm{x}}$ Scoones et al. (2018) outline a variety of ways that scholars can pursue "emancipatory research" that is "open, inclusive and collaborative". Their directives suggest concrete strategies through which land-grant scholars can pursue research that is politically and empirically embedded in the communities they serve (without compromising in theoretical or empirical rigor). "No single approach will do," they write, "each must engage in conversation with others, and respond to contextually defined questions" (Scoones et al. 2018, 12). As for land-grant scholars, the demands and capacity of individuals to pursue research that engages this political mandate will be shaped by the unique conditions of their institutions and communities. Others highlight the need for a larger process of rethinking public funding for institutions of higher education (McDowell 2003). This is work that can be done by faculty, staff, and administrators of landgrant universities both as uniquely positioned public employees and as residents of the areas in which they are based. Brady suggests that we demand a return and an expansion of public 
funding for public institutions due to their role in providing opportunities for more diverse student bodies (Brady 2018); this mandate is all the more important for land-grants.

This work of recognizing the critical political work of scholarship embodied in the land-grant mission can be supported by all academics, regardless of their professional and institutional position. A more-progressive land-grant mission aligns with the pursuit of the justice-oriented scholarship that our discipline increasingly demands in the face of the neoliberalization of universities (Lave 2015, Heynen et al. 2018). Geography as a discipline is well-positioned to engage in this civic work, particularly given the discipline's commitment to field-based learning (Barcus and Trudeau 2018). But for geographers based at land-grant universities this commitment comes with a particular responsibility to grapple with the legacies of the land-grant mission, the ways that land-grant-based work has been detrimental to many of the communities the mission was originally intended to benefit, and possibilities for aligning the land-grant mission with a more-progressive politics in the face of rising authoritarian populism. The manifesto laid out in this article is not directed at land-grant institutions' Cooperative Extension Programs exclusively; it is concerned rather with infusing this principle of engagement with the unique demands of our current political and economic moment into the work of land-grants more broadly. In this sense, the concerns outlined here should be of relevance not only to extension agents, not only to land-grant scholars, but to all scholars invested in this vision of politically engaged scholarship.

\section{Acknowledgements}

The authors thank James McCarthy for his helpful editorial comments as well as three anonymous reviewers for their suggestions, which greatly improved this manuscript. 


\section{References}

1997. Colleges of agriculture at the land grant universities: Public service and public policy. Proceedings of the National Academy of Sciences 94: 1610-1611

Akram-Lodhi, A. H. and C. Kay, Eds. 2009. Peasants and Globalization: Political economy, rural transformation and the agrarian question. London and New York, Routledge.

Antoniou, M. N and C. J. Robinson. 2017. Cornell Alliance for Science Evaluation of Consensus on Genetically Modified Food Safety: Weaknesses in Study Design. Frontiers in Public Health 5.

Barcus, H. R., and D. Trudeau. 2018. Introduction to Focus Section: Out in the World:

Geography's Complex Relationship with Civic Engagement. The Professional Geographer 70 (2): $270-276$.

Bomford, M. Yale's Land Grant History. AAG Annual Meeting, Boston, 5 April, 2017.

Bonnen, J. T. 1998. The land-grant idea and the evolving outreach university. Universitycommunity collaborations for the twenty-first century. R. M. Lerner and L. A. K. Simon. New York, Garland Publishing: 25-70. 
Brady, H. E. 2018. The Argument is Wrong and the Message is Dangerous. British Journal of Sociology 69(2): 498-505.

Brown, M. B. 2014. Climate Science, Populism, and the Democracy of Rejection." In Culture, Politics and Climate Change: How Information Shapes Our Common Future, edited by D. A. Crow and M. T. Boykoff. New York: Routledge, 129-45.

Brubacher, J. and W. Rudy. 1997. Higher Education in Transition: A History of American Colleges and Universities. New York, Routledge.

Brubaker, R. 2017. Why populism? Theory and Society 46(5): 357-385.

Busch, L. 2017. Knowledge for Sale: The Neoliberal Takeover of Higher Education. Cambridge: The MIT Press

Butler, J. 2017. "Reflections on Trump." Hot Spots, Cultural Anthropology website. Accessed 3 January 2018. https://culanth.org/fieldsights/1032-reflections-on-trump.

Buttel, F. H. and L. Busch. 1988. The Public Agricultural Research System at the Crossroads. Agricultural History 62(2): 303-24.

Canovan, M. 1999. Trust the People! Populism and the Two Faces of Democracy. Political Studies XLVII: 2-16. 
Campbell, J. R. 1995. Reclaiming a Lost Heritage: Land-Grant and Other Higher Education Initiatives for the Twenty-First Century. Aimes: Iowa State University Press.

Carravallah, L. A., et al. 2017. Lessons for Physicians from Flint's Water Crisis. AMA Journal of Ethics 19(10): 1001-1010.

Carter, P. 2017. Self-Interests, Corporatization and Rising Educational Inequality in Public Higher Education: A Review of The Great Mistake. The British Journal of Sociology 69(2): 493498

Cochrane, W.W. 1979. The Development of American Agriculture: A Historical Analysis. Minneapolis: University of Minnesota Press.

Cramer, K. J. 2016. The Politics of Resentment: Rural Consciousness in Wisconsin and the Rise of Scott Walker. Chicago: University of Chicago Press.

Crehan, K. 2016. Gramsci's Common Sense: Inequality and Its Narratives. Durham and London: Duke University Press.

Crow, M.M. and Dabars, W.B. 2015. Designing the new American university. Baltimore: Johns Hopkins University Press.

Curry, J. and M. Kenney. 1990. Land-Grant University-Industry Relationships in Biotechnology: A Comparison with the Non-Land-Grant Research Universities. Rural Sociology 55(1): 44-57. 
Edwards, J., et al. 2017. The 2016 Brexit referendum and Trump Election. American Ethnologist 44(2): 195-200.

Formisano, R. P. 2008. For the People: American Populist Movements from the Revolution to the 1850s. Chapel Hill: University of North Carolina Press.

Forsyth, T. 2011. Expertise Needs Transparency Not Blind Trust: A Deliberative Approach to Integrating Science and Social Participation. Critical Policy Studies 5(3): 317-22.

Friedmann, H., and P. McMichael. 1989. Agriculture and the State System: The rise and decline of national agricultures, 1870 to the present. Sociologia Ruralis 29 (2):93-117.

Galt, R. E., Parr, D., Van Soelen Kim, J., Beckett, J., Lickter, M., \& Ballard, H. 2012. Transformative food systems education in a land-grant college of agriculture: the importance of learner-centered inquiries. Agriculture and Human Values 30(1): 129-142.

Gauchat, G. 2012. Politicization of Science in the Public Sphere: A Study of Public Trust in the United States, 1974-2010. American Sociological Review 77(2): 167-87.

Gelber, S. 2013. The Populist Vision for Land-Grant Universities, 1880-1900. In The LandGrant Colleges and the Reshaping of American Higher Education, eds. R. L. Geiger and N. M. Sorber. New York: Routledge, 165-194. 
Glenna, L. L. 2017. The purpose-driven university: the role of university research in the era of science commercialization. Agriculture and Human Values 34(4) 1021-1031.

Goldstein, J. E., and J. Yates. 2017. Introduction: Rending land investible. Geoforum 82:209211.

Goodnough, A., M. Davey and M. Smith. 2016. Fouled Water and Failed Politics. The New York Times. 24 January. A1.

Gramsci, A. 1971. Selections from the Prison Notebooks. Moscow: International Publishers.

Guidotti, T. L. 2017. Between Distrust of Science and Scientism. Archives of Environmental \& Occupational Health 72(5): 247-48.

Gusterson, H. 2017. From Brexit to Trump: Anthropology and the Rise of Nationalist Populism. American Ethnologist 44(2): 209-14.

Halvorson, G.A. 2016. The Role of a 1994 Land Grant College. Rangelands 38(1): 14-15.

Harper, S.R., L.D. Patton, O.S. Wooden. 2009. Access and Equity for African American Students in Higher Education: A Critical Race Historical Analysis of Policy Efforts. Journal of Higher Education 80(4): 389-414. 
Hall, S. 1980. Popular-Democratic vs Authoritarian Populism: Two Ways of 'Taking Democracy Seriously'. Marxism and Democracy. London, Lawrence and Wishart: 157-185.

Hall, S. 1985. Authoritarian Populism: A Reply to Jessop et al. New Left Review I/151: 115-124.

Hanna-Attisha, M., et al. 2016. Elevated Blood Levels in Children Associated With the Flint Drinking Water Crisis: A Spatial Analysis of Risk and Public Health Response. American Journal of Public Health 106(2): 283-290.

Heynen, N., D. Aiello, C. Keegan \& N. Luke. 2018. The Enduring Struggle for Social Justice and the City, Annals of the American Association of Geographers, 108(2): 301-316.

Hightower, J. 1972. Hard Tomatoes, Hard Time: Failure of the Land Grant College Complex. Society 10(1): 10-22.

Kellog Commission. 1999. Returning to Our Roots: The Engaged Institution. Third report of the Kellogg Commission. Washington DC: National Association of State Universities and LandGrant Colleges.

Kenney-Lazar, M., and K. Kay. 2017. Value in capitalist natures. Capitalism Nature Socialism $28(1): 33-38$.

Lave, R. 2012. Neoliberalism and the Production of Environmental Knowledge. Environment and Society: Advances in Research, 3(1) 19-38. 
Lave, R. 2015. The Future of Environmental Expertise. Annals of the Association of American Geographers, 105(2), 244-252.

Lewis-Beck, M. S. 1977. Agrarian Political Behavior in the United States. American Journal of Political Science 21(3): 543-65.

Lichter, D. T and J. P Ziliak. 2017. The Rural-Urban Interface: New Patterns of Spatial Interdependence and Inequality in America. ANNALS of the American Academy of Political and Social Science 672: 6-25.

Mack, E.A. and K. Stolarick. 2014. The gift that keeps on giving: land-grant universities and regional prosperity. Environment and Planning C: Government and Policy 32(3): 384-404

McDowell, G. R. 2003. Engaged Universities: Lessons from the Land-Grant Universities and Extension. The Annals of the American Academy of Political and Social Science 585:31-50.

Michigan State University. 2017. MSU and Flint: Partnering for a Healthier Future. Retrieved 30 December, 2017.

Mirowski, Philip 2011. Science Mart: Privatizing American Science. Cambridge: Harvard University Press. 
Monnat, S. M and D. L. Brown. 2017. More Than a Rural Revolt: Landscapes of Despair and the 2016 Presidential Election. Journal of Rural Studies 55: 227-36.

National Research Council. 1996. Colleges of Agriculture at the Land Grant Universities: Public Service and Public Policy. Washington, DC: National Academy Press.

Newfield, C. 2016. The Great Mistake: How We Wrecked Public Universities and How We Can Fix Them. Baltimore: Johns Hopkins University Press.

Oliver, M. L. and T. M. Shapiro. 1997. Black Wealth/White Wealth: A New Perspective on Racial Inequality. New York, Routledge.

Osborne, T. 2017. Public Political Ecology: A Community of Praxis for Earth Stewardship. Journal of Political Ecology, 24: 843-860.

Paprocki, K. 2018. All That Is Solid Melts into the Bay: Anticipatory Ruination and Climate Change Adaptation. Antipode. DOI:10.1111/anti.1242.

Peters, S.J. 2006. Every Farmer Should Be Awakened: Liberty Hyde Bailey's Vision of Agricultural Extension Work. Agricultural History, 190-219.

Peters, S., T.R. Alter, and N. Schwartzbach. 2008. Unsettling a Settled Discourse: Faculty Views of the Meaning and Significance of the Land-Grant Mission. Journal of Higher Education Outreach and Engagement. 12 (2): 33-65. 
Public Political Ecology Lab. 2015. http://ppel.arizona.edu/.

Putsche, L., L. Hormel, J. Mihelich, and Debbie Storrs. 2017. 'You End up Feeling Like the Rest of the World Is Kind of Picking on You': Perceptions of Regulatory Science's Threats to Economic Livelihoods and Idahoans' Collective Identity. Science Communication 39(6): 687712.

Ranganathan, M. 2016. Thinking with Flint: Racial Liberalism and the Roots of an American Water Tragedy. Capitalism Nature Socialism 27(3): 17-33.

Reston, L. 2015. Donald Trump Isn't the First Know Nothing to Capture American Hearts. New Republic.

Sadler, R. C. and A. R. Highsmith 2016. Rethinking Tiebouth: the contribution of political fragmentation and racial/economic segregation to the Flint water crisis. Environmental Justice 9(5): 143-151.

Schiff, J. 2009. When Yale Was a Farming School. Yale Alumni Magazine LXXII, 4.

Schnurr, M. A. 2015. Gmo 2.0: Genetically Modified Crops and the Push for Africa's Green Revolution. Canadian Food Studies 2(2): 201-08. 
Scoones, I., M. Edelman, S.M. Borras Jr., R. Hall, W. Wolford, B. White. 2018. Emancipatory

rural politics: confronting authoritarian populism. Journal of Peasant Studies 45(1): 1-20.

Steinmetz, G. 2005. The Politics of Method in the Human Science: Positivism and Its

Epistemological Others. Durham/London: Duke University Press.

Ulrich-Schad, J. D., \& Duncan, C. M. 2018. People and places left behind: work, culture and politics in the rural United States. Journal of Peasant Studies 45(1), 59-79.

Williams, T. T and H. Williamson, Jr. 1988. Teaching, Research, and Extension Programs at Historically Black (1890) Land-Grant Institutions. Agricultural History 62(2): 244-57.

\footnotetext{
${ }^{\mathrm{i}}$ The authors initiated the conversations that resulted in this piece while each of us was either a faculty member or a PhD student at a U.S. land-grant university.

ii By common sense, Gramsci (and, by extension, Hall, who draws on Gramsci) refers to the diverse beliefs and seemingly-self evident truths that both derive from and entrench class-based cultural, political, and economic hegemony (see also Crehan 2016).

iii The 1887 Hatch Act established colleges of agriculture within the land-grant system and focused on serving rural communities through agricultural extension. However, McDowell importantly points out that this agricultural focus has never been the sole objective of the land-grant mission, writing that "for many inside and outside Land-Grant universities, the Land-Grant principle, whatever it means, is explicitly agricultural. That misunderstanding of a principle central to the Land-Grant universities continues to mislead and confound the understanding of an insight significant to the future of the academy and higher education" (McDowell 2003, 33).

iv The populist politics of the Confederacy itself are perhaps the greatest example of this (Isenberg 2016); however the xenophobic "Know Nothing Party" (Formisano 2008) - the politics of which have been compared with those of Donald Trump (Reston 2015) - represented an early strand of authoritarian populism. Abraham Lincoln's own strand of populist politics resulted in the Homestead Act of 1862, under the federal government gave small grants of agricultural lands west of the Mississippi to non-Confederate white Americans (Oliver and Shapiro 1997).

${ }^{\mathrm{v}}$ There are currently 17 historically black colleges designated as land-grant institutions.

${ }^{v i}$ Indeed, voter dissatisfaction with land-grant institutions was expressed dramatically when the Connecticut General Assembly revoked the land-grant charter from Yale, which had been one of the first land-grant institutions. The large agricultural voting bloc objected to what it perceived to be elitist admissions standards and a curriculum that did not serve Connecticut farmers (Schiff 2009, Bomford 2017).
} 
${ }^{\text {vii }}$ Cf. Global analysis of the agrarian question (Akram-Lodhi and Kay 2009, Edelman et al. 2014), within which the transnational role of the United States has largely been paid greater attention than rural-urban transitions within the United States itself.

viii Cornell University's Alliance for Science is one example, a program funded by the Bill and Melinda Gates foundation that supports research on and advocacy for genetically modified crops and foods (Antoniou and Robinson 2017, Schnurr 2015).

ix Here we direct attention to the alternative populist visions that Hall referred to as "popular-democratic" (Hall 1980).

${ }^{\mathrm{x}}$ The capacity of individual scholars to negotiate these possibilities is deeply inequitably distributed based on professional demands and hierarchies, including requirements and incentives for hiring and promotion and the rise of contingent academic labor contracts. 